Título artículo / Títol article:

The dark side of technologies:

Technostress among users of information and communication technologies

Salanova Soria, María Luisa Llorens Gumbau, Susana Cifre Gallego, Eva

International Journal of Psychology, 2013, 48.3

Versión / Versió: $\quad$ Post-print de l'autor

Cita bibliográfica / Cita bibliogràfica (ISO 690):
SALANOVA, Marisa; LLORENS, Susana; CIFRE, Eva. The dark side of technologies: Technostress among users of information and communication technologies. International Journal of Psychology, 2013, 48.3: 422-436.

url Repositori UJI: http://hdl.handle.net/10234/87250 


\title{
The dark side of technologies: Technostress among users of information and communication technologies
}

\author{
Marisa Salanova, Susana Llorens, and Eva Cifre \\ Department of Social Psychology, University Jaume I, Castellón, Spain
}

\begin{abstract}
$T$ his paper tests the structure and the predictors of two psychological experiences of technostress associated with the use of information and communication technologies (ICT), i.e., technostrain (users report feelings of anxiety, fatigue, scepticism and inefficacy beliefs related to the use of technologies) and technoaddiction (users feel bad due to an excessive and compulsive use of these technologies). The study included a sample of 1072 ICT users ( $N=675$ nonintensive ICT users and $N=397$ intensive ICT users). Results from multigroup confirmatory factor analyses among non-intensive and intensive ICT users showed, as expected, the four-factor structure of technostrain in both samples. Secondly, and also as expected, confirmatory factorial analyses revealed that technostress experiences are characterized not only by technostrain but also by an excessive and compulsive use of ICT. Moreover, multiple analyses of variance showed significant differences between non-intensive and intensive ICT users (1) in the dimensions of technostress and (2) in specific job demands and job/personal resources. Finally, linear multiple regression analyses revealed that technostrain is positively predicted by work overload, role ambiguity, emotional overload, mobbing and obstacles hindering ICT use, as well as by lack of autonomy, transformational leadership, social support, ICT use facilitators and mental competences. Work overload, role ambiguity and mobbing, as well as the lack of emotional competences, positively predict technoaddiction. Theoretical and practical implications, in addition to future research, are discussed.
\end{abstract}

Keywords: Technostress; Technostrain; Technoaddiction; ICT.

C et article porte sur la structure et les facteurs prédictifs de deux expériences psychologiques de technostress associées à l'utilisation des Technologies de l'information et de la communication (TIC), c'est-à-dire la technotension (les utilisateurs rapportent des sentiments d'anxiété, de fatigue, de scepticisme et de croyance d'inefficacité reliés à l'utilisation des technologies) et la technodépendance (les utilisateurs ressentent un malaise causé par une utilisation excessive et compulsive des technologies). L'étude a été réalisée auprès d'un échantillon de 1072 utilisateurs de TIC (675 utilisateurs non intensifs et 397 utilisateurs intensifs). Les résultats d'analyses factorielles confirmatoires multigroupes ont soulevé une structure à quatre facteurs pour la technotension pour chacun des deux groupes, tel qu'attendu. Deuxièmement, également conformément à nos attentes, les analyses factorielles confirmatoires ont révélé que les expériences de technostress ne sont pas seulement caractérisées par la technotension, mais aussi par une utilisation excessive et compulsive des TIC. De plus, les analyses de variance multiples ont montré des différences significatives entre les utilisateurs non intensifs et les utilisateurs intensifs des TIC (1) pour les dimensions de technostress et (2) pour les exigences spécifiques de l'emploi et pour les ressources au travail ou personnelles. Finalement, des analyses de régression linéaire multiple ont révélé que la technotension est positivement prédite par la surcharge de travail, l'ambigüité du rôle, la surcharge émotionnelle, le mobbing et les obstacles entravant l'utilisation des TIC, tout comme par le manque d'autonomie, de leadership transformationnel, de soutien social, de facilitateurs dans l'utilisation des TIC et de compétences mentales. La surcharge de travail, l'ambigüité du rôle et le mobbing, tout comme le manque de compétences émotionnelles prédisent positivement la technodépendance. Les implications théoriques et pratiques, ainsi que les avenues de recherche future, sont discutées.

Correspondence should be addressed to Marisa Salanova, Dpto. Psicologia Evolutiva, Educativa, Social y Metodologia, University Jaume I, Avda. Sos Baynat s/n, C.P. 12071, Castellón de la Plana, Spain. (E-mail: salanova@uji.es).

(C) 2012 International Union of Psychological Science 


\begin{abstract}
$E$ ste trabajo pone a prueba la estructura y los predictores de dos experiencias psicológicas de tecnoestrés asociadas con el uso de Tecnologías de la Información y Comunicación (TIC), es decir, la tecnostrain (los usuarios registran sentimientos de ansiedad, fatiga, escepticismo e ineficacia relacionadas con el uso de las tecnologías) y tecnoadicción (los usuarios se sienten mal debido a un uso excesivo y compulsivo de estas tecnologías). El estudio utilizó una muestra de 1072 usuarios de TIC ( $N=675$ usuarios no intensivos de TIC; y $N=397$ usuarios intensivos de TIC). Los resultados de los análisis factoriales confirmatorios multigrupo entre los usuarios no intensivos e intensivos de TIC mostraron, como se esperaba, la estructura de cuatro factores de tecnostrain en ambas muestras. En segundo lugar, y también como se esperaba, el análisis factorial confirmatorio reveló que las experiencias de tecnoestrés no sólo se caracterizan por el tecnostrain sino también por un uso excesivo y compulsivo de las TIC. Por otra parte, los análisis de varianza múltiple muestran diferencias significativas entre los usuarios no intensivos e intensivos de las TIC (1) en las dimensiones de tecnoestrés y (2) en las demandas específicas del trabajo y los recursos laborales/personales. Por último, los análisis de regresión lineal múltiple revelaron que el tecnostrain es predicho positivamente por la sobrecarga de trabajo, la ambigüedad de rol, sobrecarga emocional, mobbing y obstáculos que impiden el uso de TIC, así como por la falta de autonomía, liderazgo transformacional, apoyo social, facilitadores del uso de TIC y competencias mentales. La sobrecarga de trabajo, ambigüedad del rol y mobbing, así como la falta de competencias emocionales predicen positivamente la tecnoadicción. También se discuten en este estudio las implicaciones teóricas y prácticas, además de futuras líneas de investigación.
\end{abstract}

One of the more attractive goals to be achieved by introducing information and communication technologies (ICT) was to make our lives easier (i.e., by providing faster communications around the globe, efficacy in work processes, and so on). If modern technology was designed to empower us, to set us free, and to leave us satisfied, why do we often feel (techno-)stressed due to the use of this technology? Why does using email or the Internet sometimes lead to discomfort, anxiety and physical troubles?

Technostress is a specific type of stress related to the use of ICT, mostly resulting from the high speed at which technological change takes place (Şahin \& Çoklar, 2009). Although different definitions of technostress have been put forward (Brod, 1984; Weil \& Rosen, 1997), most of them include psychological, physical, or behavioral strain responses to technostressors (Al-Fudail \& Mellar, 2008) or technostrain (Cooper, Dewe, \& O'Driscoll, 2001). For example, Wang, Shu, and $\mathrm{Tu}$ (2008, p. 3004) defined technostress as a "reflection of one's discomposure, fear, tenseness and anxiety when one is learning and using computer technology directly or indirectly that ultimately ends in psychological and emotional repulsion and prevents one from further learning or using computer technology." Focusing on workplace settings, Salanova, Llorens, Cifre and Nogareda (2007) proposed a definition of the technostress experience at work as a "negative psychological state associated with the use or threat of ICT use in the future. This experience is related to feelings of anxiety, mental fatigue, scepticism and inefficacy" (p. 1). This will be the definition used in the current study.
While most previous research on technostress has focused mainly on its predictors or antecedents (i.e., ICT usability, implementation process) (Hamborg \& Greif, 2009; Parayitam, Desai, Desai, \& Eason, 2010) and/or its consequences (Ragu-Nathan, Tarafdar, Ragu-Nathan, \& Tu, 2008), to date little research has examined the actual psychological experience of technostress itself. One of the issues addressed in the current study is the understanding of the psychological experience of technostress. Specifically, we propose that the term technostress acts as an umbrella encompassing two different but related psychological experiences: technostrain and technoaddiction.

\section{TECHNOSTRAIN: THE ORTHODOX EXPERIENCE OF ICT STRAIN}

Workers experiencing technostrain feel a combination of high levels of anxiety, fatigue, scepticism and inefficacy related to the use of ICT (Salanova et al., 2007), anxiety and fatigue being the most common affective experiences. Classical studies on affect at work (Larsen \& Diener, 1992; Russell, 1980; Warr, 1987) place emotions in a twodimensional pleasant-unpleasant and activateddeactivated space. Anxiety is the orthodox component of stress, where the person experiences high levels of physiological activation and feels tension and discomfort with respect to ICT. Computer anxiety is one of the most widely studied technostrain experiences and it has been used as a term to describe the fear, apprehension, and agitation that individuals experience when interacting with, or 
thinking about, computers (Gaudron \& Vignoli, 2002). These negative feelings include the fear of hitting a wrong key and losing information, doubts about using computers for fear of making a mistake, and finding computers intimidating (cf. Ragu-Nathan et al., 2008).

But people can also experience other negative psychological experiences such as fatigue and exhaustion due to the use of technologies, which are characterized by lower levels of psychological activation. Lewis (1996) drew attention to information fatigue syndrome (IFS) as a specific type of fatigue resulting from the use of ICT (Internet, email, smartphones, tablets, social networks) that derives from the current requirements of the Information Society and from dealing with information overload. This could lead to poor decisionmaking, difficulty in memorizing and remembering, and a reduced attention span.

The third component in the technostrain experience is a kind of sceptical and distant attitude toward the use of ICT. The term "scepticism" is based on the broader studies conducted on job burnout, and more specifically on its "cynicism" component (Maslach, Schaufeli, \& Leiter, 2001; Schaufeli \& Enzmann, 1998). In the technostrain experience, "scepticism" is defined as the display of indifferent, detached, and distant attitudes toward the use of ICT (Schaufeli \& Salanova, 2007). This is a feeling of cognitive distancing that consists of developing indifference or a cynical attitude when users are exhausted and discouraged due to the use of ICT.

Finally, feeling inefficacious in the use of ICT is the fourth (cognitive) component of technostrain and refers to the perceived level of inefficacy when using ICT (Schaufeli \& Salanova, 2007). When ICT users have to cope with chronic, overwhelming demands that contribute to anxiety, fatigue and scepticism, their sense of efficacy is likely to be reduced. It is quite difficult to display efficacy when feeling exhausted or when one feels indifferent to ICT use. Research has shown that ICT selfefficacy (Salanova, Grau, Cifre, \& Llorens, 2000) affects whether a person chooses to use technologies, the effort and the persistence they expend, and the performance achieved with the use of ICT. Moreover, ICT self-efficacy has been shown to motivate the ongoing computer user (Deng, Doll, \& Truong, 2004) and to play a shock-absorbing role against burnout (Salanova et al., 2000) and anxiety related to ICT (Henderson, Deane, \& Ward, 1995) in the sense that it can reduce the negative impact of ICT use leading to technostrain.

\section{TECHNOADDICTION: WORKING WITH ICT EXCESSIVELY AND COMPULSIVELY}

As Ookita and Tokuda (2001) suggested, the new psychological illnesses stemming from ICT use may range from technostrain to technoaddiction. Addiction to technology is a so-called behavioural addiction that involves human-machine interaction and usually includes inducing and reinforcing features that may contribute to the promotion of addictive tendencies (Griffiths, 1995).

Specifically, the study of technoaddiction is based on the more traditional workaholism literature; that is, the tendency to work excessively hard (i.e., by allocating large amounts of time to work beyond what can reasonably be expected) in a compulsive way (by obsessive, persistent, and frequent thinking about work even when not actually working) (Schaufeli, Taris, \& Bakker, 2008). Recently, Del Libano, Llorens, Salanova, and Schaufeli (2010) empirically evidenced this two-factor structure of workaholism among employees from different countries. Interestingly, workaholism and technoaddiction might go together, as there is a connection between working excessively and the use of ICT (Porter \& Kakabadse, 2006).

From this similarity it is proposed that technoaddiction is a specific technostress experience due to an uncontrollable compulsion to use ICT "everywhere and anytime" and to use it for long periods of time in an excessive way. A related concept called problematic Internet use (PIU) has been studied in college samples (Huang et al., 2009) but, to our knowledge, little research has been conducted in adult samples on technoaddiction while working. Empirical results of those studies showed that the more technoaddiction there is, the less psychosocial wellbeing (i.e., the more anxiety and fatigue) there will be (Huang, 2010; Schiffrin, Edelman, Falkenster, \& Steward, 2010). Technoaddicts use ICT because "they have to use it" (compulsion) and feel anxious when they are not using it. Furthermore, using ICT in excess is related to fatigue, since performing an activity to a higher extent than usual produces a decrease in arousal and energy.

\section{PREDICTORS OF TECHNOSTRESS EXPERIENCES}

When one is focusing on antecedents of technostress, the data analyzed include the specific 
characteristics of the technology itself, such as ICT usability or its implementation process (Hamborg \& Greif, 2009; Parayitam et al., 2010). In this line, some authors have included under the name of "technostress creators" certain factors that predict technostress, such as techno-overload, technoinsecurity, techno-invasion, techno-uncertainty and techno-complexity (see Ragu-Nathan et al., 2008). In addition, at the organizational level, research has shown the effect that different organizational environment settings have on technostress, such as both highly centralized and highly innovative companies (Wang et al., 2008). Finally, Wallgren and Hanse (2007) demonstrated the relationship between job characteristics (job demand, job control) and stress among information technology consultants, showing that job demands were positively related to perceived stress. Job control, however, was negatively related to job stress partially mediated by "motivators" (e.g., responsibility, recognition, achievement, possibility of growth). In this regard, Korunka, Zauchner, and Weiss (1997) showed that the stress experienced by workers dealing with continuous implementations was highly influenced by contextual factors such as decision latitude or job control as key job characteristics to be considered.

This previous research supports the so-called resources-experiences-demands (RED) model (Salanova, Cifre, Llorens, Martínez, \& Lorente, 2011), which extends the job demands-resources (JDR) model (Demerouti, Bakker, Nachreiner, \& Schaufeli, 2001) and the dual process model (Schaufeli \& Bakker, 2004). The RED model postulates that the amount of stress experienced at work is the result of the combination of job demands and a scarcity of job resources to cope with those demands and also "personal resources." These personal resources (i.e., mental and emotional competences) affect the stress process not only through the appraisal of the situation but also through the actual coping process and recovery from the job stress process. It is assumed that an "energy-draining process" that leads to exhaustion and long-term burnout occurs due to the existence of high job demands and lack of resources (Schaufeli \& Bakker, 2004). Taking these models as a base, and focusing on the aim of the current research, we would expect the existence of job demands and the lack of job resources to be related to the technostress (both technostrain and technoaddiction) experience, as a result of the energydraining process.

\section{THE CURRENT STUDY}

Based on previous research, the aim of this study is to test the structure and the predictors of two specific technostress experiences (technostrain and technoaddiction) in the workplace. More specifically, we expect the following.

- Hypothesis 1: The psychological experience of technostrain in ICT users is composed of four independent but positively interrelated components, namely anxiety, fatigue, skepticism, and feelings of inefficacy related to ICT use.

- Hypothesis 2: The technoaddiction experience in intensive ICT users is composed of two independent but interrelated components: excessive and compulsive ICT use.

- Hypothesis 3: Job demands, job resources, and personal resources are predictors of both technostrain and technoaddiction. Specifically, we expect job demands to be positively related to technostrain and technoaddiction, while job and personal resources are negatively related to technostrain and technoaddiction.

\section{METHODS}

\section{Participants and Procedure}

A total of 1072 ICT users were considered in this cross-sectional design, which includes two samples according to the intensity of ICT use. The first sample consisted of 675 (52\% women) nonintensive users who commonly utilize ICT as just another tool at work, but not in a frequent way (i.e., daily and during most of the workday). The mean age was 34 years $(S D=8.98)$, ranging from 18 to 58 years. Fifty percent had a full-time work contract; they had worked for an average of seven years in the company and did a variety of jobs (54\% technical and qualified professionals, 22\% supervisors, $13 \%$ managers, and $11 \%$ blue-collar workers).

The second sample consisted of 397 intensive users of ICT ( $62 \%$ women), for whom ICT is the "basic" tool for their work. They work in an educational organization in which the services they provide for the students are offered exclusively on a virtual basis, and the contact with them is carried out online. Fifty-seven percent had a full-time contract; they had with an average of 5.8 years working in the company. As occurs in other addictions such as substance addictions, the individuals in this sample, who had greater exposure to ICT during their working days, were 
expected to be more susceptible to technoaddiction. We have no data about the age of this sample since the company, as a strategy to guarantee the anonymity of the participants, did not disclose this information.

\section{Measures}

We used 20 original, reworded, or adapted versions of well-known, validated scales (see Table 1 for details). Specifically, technostrain was assessed by four previously validated scales
(Salanova et al., 2007): anxiety, fatigue, scepticism, and inefficacy. Technoaddiction was measured by two previously validated scales from the Spanish version of UWAS (Utrecht Workaholism Scale) by Del Libano et al. (2010), but for the current study the items were reworded to fit ICT settings.

Job demands, job resources and personal resources were measured by previously validated scales from the RED questionnaire (validated by Salanova et al., 2011), which included a total of 14 scales split into job demands (eight scales, i.e., work overload, role ambiguity, role conflict, monotony, mental overload, emotional overload,

TABLE 1

Scales, number of items (for non-intensive/intensive users), Cronbach's $\alpha$ of the original scale, source, and an example of an item

\begin{tabular}{|c|c|c|c|c|}
\hline Scale & Item & Alpha & Source & Example of item \\
\hline 1. Anxiety & $4 / 4$ & .83 & Salanova et al., 2007 & $\begin{array}{l}\text { 'I feel tense and anxious when I work } \\
\text { with ICT' }\end{array}$ \\
\hline 2. Fatigue & $4 / 4$ & .92 & Salanova et al., 2007 & $\begin{array}{l}\text { 'It is difficult for me to relax after a } \\
\text { day's work using ICT' }\end{array}$ \\
\hline 3. Scepticism & $4 / 4$ & .93 & Salanova et al., 2007 & $\begin{array}{l}\text { 'As time goes by, ICT interest me less } \\
\text { and less' }\end{array}$ \\
\hline 4. Inefficacy & $4 / 4$ & .84 & Salanova et al., 2007 & $\begin{array}{l}\text { 'In my opinion, I am inefficacious when } \\
\text { using ICT' }\end{array}$ \\
\hline 5. Working excessively & $3 / 3$ & .78 & *Del Libano et al., 2010 & 'I feel I use ICT in excess in my life' \\
\hline 6. Working compulsively & $3 / 3$ & .79 & *Del Libano et al., 2010 & $\begin{array}{c}\text { 'I seem to have an inner compulsion to } \\
\text { use ICT in whatever place and time' }\end{array}$ \\
\hline 7. Work overload & $5 / 5$ & .90 & **Beehr, Walsh, \& Taber, 1976 & 'I have more work that I can do' \\
\hline 8. Role ambiguity & $4 / 4$ & .76 & **Rizzo, House, \& Lirtzman, 1970 & $\begin{array}{l}\text { 'My job requires me to do things which } \\
\text { are disorganized' }\end{array}$ \\
\hline 9. Role conflict & $5 / 3$ & .72 & $* *$ Rizzo et al., 1970 & $\begin{array}{l}\text { 'My job requires me to do things which I } \\
\text { don't agree with' }\end{array}$ \\
\hline 10. Monotony & $3 / 3$ & .91 & Salanova et al., 2011 & $\begin{array}{l}\text { 'My job requires me to do monotonous } \\
\text { tasks' }\end{array}$ \\
\hline 11. Mental overload & $3 / 3$ & .85 & **Van Veldhoven \& Meijman, 1994 & $\begin{array}{l}\text { 'My job requires a great deal of } \\
\text { attention and concentration from me } \\
\text { to do my work' }\end{array}$ \\
\hline 12. Emotional overload & $8 / 3$ & .86 & **Van Veldhoven \& Meijman, 1994 & $\begin{array}{l}\text { 'In my job, I must be able to deal with } \\
\text { difficult people' }\end{array}$ \\
\hline 13. Mobbing & $4 / 4$ & .86 & Salanova et al, 2007 & $\begin{array}{l}\text { 'It has limited my access to maliciously } \\
\text { promotions, or training courses to } \\
\text { hurt me' }\end{array}$ \\
\hline 14. ICT use obstacles & $4 / 4$ & .80 & Salanova et al., 2007 & $\begin{array}{l}\text { 'Hardware problems such as bad con- } \\
\text { figuration with peripheral slowdown } \\
\text { problems, exhaustion of supplies' }\end{array}$ \\
\hline 15. Autonomy & $4 / 4$ & .91 & $* *$ Jackson et al., 1983 & $\begin{array}{l}\text { 'I have autonomy to decide when to } \\
\text { start, when to finish and in which } \\
\text { order tasks are to be done' }\end{array}$ \\
\hline 16. Transformational leadership & $10 / 10$ & .86 & Salanova et al., 2011 & $\begin{array}{l}\text { 'The person who supervises me directly } \\
\text { organizes and distributes } \\
\text { responsibilities' }\end{array}$ \\
\hline 17. Social support & $4 / 3$ & .77 & Salanova et al., 2011 & $\begin{array}{l}\text { 'My job requires me to do monotonous } \\
\text { tasks' }\end{array}$ \\
\hline 18. ICT use facilitators & $4 / 4$ & .80 & Salanova et al., 2007 & $\begin{array}{l}\text { 'Availability of different communication } \\
\text { channels (email, mailing lists, etc.)' }\end{array}$ \\
\hline 19. Mental competences & $3 / 3$ & .85 & **Van Veldhoven \& Meijman, 1994 & $\begin{array}{l}\text { 'In my job, I am able to work with a lot } \\
\text { of information' }\end{array}$ \\
\hline 20. Emotional competences & $8 / 3$ & .86 & **Van Veldhoven \& Meijman, 1994 & $\begin{array}{l}\text { 'In my job, I must be able to deal with } \\
\text { difficult people' }\end{array}$ \\
\hline
\end{tabular}

*reworded scale, **adapted scale. 
TABLE 2

Descriptive analyses and internal consistencies (Cronbach's $\alpha$ ) for technostress for non-intensive $(N=675)$ and intensive $(N=397)$ ICT users

\begin{tabular}{|c|c|c|c|c|c|c|c|c|c|c|}
\hline & \multicolumn{3}{|c|}{ Non-intensive users } & \multicolumn{3}{|c|}{ Intensive users } & \multirow[b]{2}{*}{ (1) } & \multirow[b]{2}{*}{ (2) } & \multirow[b]{2}{*}{ (3) } & \multirow[b]{2}{*}{ (4) } \\
\hline & $M$ & $S D$ & $\alpha$ & $M$ & $S D$ & $\alpha$ & & & & \\
\hline 1. Anxiety & 1.13 & 1.14 & .84 & .86 & .91 & .83 & - & $.61 * * *$ & $.43 * * *$ & $.76^{* * *}$ \\
\hline 2. Fatigue & 1.44 & 1.25 & .90 & 1.55 & 1.38 & .94 & $.56^{* * *}$ & - & $.36^{* * *}$ & $.47 * * *$ \\
\hline 3. Scepticism & 1.33 & 1.14 & .79 & 1.16 & 1.08 & .82 & $.41 * * *$ & $.33 * * *$ & - & $.45^{* * *}$ \\
\hline 4. Inefficacy & .98 & 1.11 & .85 & .65 & .82 & .87 & $.70 * * *$ & $.36^{* * *}$ & $.38 * * *$ & - \\
\hline 5. Addiction & - & - & - & 2.39 & 1.33 & .85 & $.17 * *$ & $.24 * * *$ & .04 & .01 \\
\hline
\end{tabular}

$* * * p<.001, * * p<.01$. Correlations for intensive users below the diagonal.

mobbing, and obstacles hindering ICT use), job resources (four scales, i.e., autonomy, transformational leadership, social support, and ICT use facilitators), and personal resources (two scales, i.e., mental and emotional competences) in both non-intensive and intensive ICT users. For the current study, the items were also reworded to fit ICT settings.

Respondents answered items about technostrain and technoaddiction, as well as job demands, job resources, and personal resources, using a sevenpoint scale ranging from 0 (never) to 6 (always/ every day).

\section{Data analyses}

First, we calculated internal consistencies (Cronbach's $\alpha$ ), descriptive analyses and intercorrelations using SPSS 19.0. Second, different Confirmatory Factor Analyses (CFA) analyses were computed using AMOS 19.0 (Analysis of Moment Structures) in order to test for: (1) bias due to common method variance with Harman's single-factor test (cf. Podsakoff, MacKenzie, Lee, \& Podsakoff, 2003); (2) the factorial structure of the dimensions of the technostress experience (technostrain) using multi-group analyses (MLG; Byrne, 2006) in ICT users $(N=1072)$ by comparing two plausible models: M1, in which all the items load on a single latent factor (technostrain), and M2, in which items load on four dimensions of technostrain; and (3) the structure of the technostress experience (technostrain and technoaddiction) in intensive ICT users. Different fit indices were tested: the root mean square error of approximation (RMSEA), the comparative fit index (CFI), the incremental fit index (IFI), and the Akaike information criterion (AIC). Values below .08 for the RMSEA, the lower the better for the AIC, and above .90 for the rest of the indices indicate an acceptable fit.
Third, we computed two multiple analyses of variance (MANOVAs): (1) using the ICT sample (non-intensive and intensive users) and the dimensions of technostrain (anxiety, fatigue, scepticism, and inefficacy), and (2) using the ICT sample (nonintensive and intensive users) and the predictors of technostrain, i.e., job demands, job resources, and personal resources. Finally, SPSS 19.0 was used again to implement two linear multiple regression analyses using the forced entry method to determine the relationships among job demands, job and personal resources, and technostress (both technostrain and technoaddiction). This method is recommended as the best when all the predictors are forced into the model simultaneously (Berntson \& Marklum, 2007; Field, 2005). Furthermore, it also allows the proportion of common variance between different variables to be determined through the coefficient of determination $\left(R^{2}\right.$; Everitt, 2002). In both linear regression analyses, job demands, job resources, and personal resources were introduced into the first, second, and third step, respectively.

\section{RESULTS}

\section{Descriptive analyses for technostress}

Table 2 gives the descriptive analyses and Cronbach's alpha of the variables of technostress for both samples. The alpha values meet the criterion of .70 (Nunnally \& Bernstein, 1994). As expected, the pattern of correlations shows that anxiety, fatigue, scepticism, and inefficacy are positively and significantly related in both samples. However, in intensive ICT users, two nonsignificant correlations are observed between technoaddiction and scepticism and inefficacy. The Harman's single factor test reveals a bad fit to the data in both non-intensive, $\chi^{2}(104)=2265.71, \quad \mathrm{RMSEA}=.17, \quad \mathrm{CFI}=.67$, 
TABLE 3

Fit indices of the multigroup confirmatory factor analyses of technostrain in ICT users $(N=1072)$

\begin{tabular}{|c|c|c|c|c|c|c|c|c|c|c|c|}
\hline Model & $\chi^{2}$ & $d f$ & RMSEA & $C F I$ & $I F I$ & $A I C$ & $\chi^{2}$ diff & $\triangle R M S E A$ & $\triangle C F I$ & $\triangle I F I$ & $\triangle A I C$ \\
\hline 1. Model 1: 1 factor & 4310.83 & 208 & .14 & .62 & .56 & 4438.83 & & & & & \\
\hline 2. Model 2: 4 factors & 1208.79 & 196 & .07 & .91 & .91 & 1360.79 & & & & & \\
\hline Diff. M2 \& M1 & & & & & & & $3102.04 * * *$ & .7 & .29 & .35 & 3078.04 \\
\hline 3. Model 2 revised & 895.57 & 192 & .05 & .94 & .94 & 1055.57 & & & & & \\
\hline Diff. M2revised \& M2 & & & & & & & $313.22 * * *$ & .02 & .03 & .03 & 305.22 \\
\hline 4. Model 3: full constrained & 991.17 & 212 & .06 & .93 & .93 & 1117.17 & & & & & \\
\hline Diff. M3 \& M2revised & & & & & & & $95.6^{* * *}$ & .01 & .01 & .01 & 61.6 \\
\hline 5. Model 4: equal covariances & 938.26 & 200 & .06 & .93 & .93 & 1082.21 & & & & & \\
\hline Diff. M4 \& M2revised & & & & & & & $42.69 * * *$ & .01 & .01 & .01 & 26.64 \\
\hline 6. Model 5: equal factor weights & 946.01 & 204 & .06 & .93 & .93 & 1062.02 & & & & & \\
\hline Diff. M5 \& M2revised & & & & & & & $50.44 * * *$ & .01 & .01 & .01 & 6.45 \\
\hline 7. Model 6: final & 912.91 & 204 & .06 & .93 & .93 & 1048.91 & & & & & \\
\hline Diff. M6 \& M2revised & & & & & & & 17.34 & .01 & .01 & .01 & 6.66 \\
\hline
\end{tabular}

$\chi^{2}=$ Chi-square; $\mathrm{df}=$ degrees of freedom; RMSEA = root mean square error of approximation; CFI = comparative fit index; $\mathrm{IFI}=$ incremental fit index; $\mathrm{AIC}=$ Akaike information criterion; $* * * p<.001$.

$\mathrm{IFI}=.67, \mathrm{AIC}=2329.71$, and intensive ICT users, $\chi^{2}(104)=2045.17, \quad$ RMSEA $=.22, \quad \mathrm{CFI}=.55$, $\mathrm{IFI}=.55, \mathrm{AIC}=2109.17$. A single factor could not account for the variance and, consequently, common method variance is not a serious deficiency in this dataset.

\section{Confirmatory factorial structure of technostrain}

Table 3 gives the results of CFA with MLG analyses on technostrain for both samples, analysed simultaneously (multigroup analyses). Compared to the one-factor model (M1), results indicate that the four-factor model (M2), delta $\chi^{2}(12)=3102.04, p<.001$, is the one that best fits the data. Analyses of the modification index reveal that the model improves significantly, delta $\chi^{2}(4)=313.22, p<.001$, if two pairs of errors are correlated (anxiety2-anxiety3 and scepticism1scepticism $2^{1}$ respectively). The final model (M2 revised) is represented graphically in Figure 1 with factor weight values higher than .52 for the non-intensive and .54 for the intensive ICT users, and with latent factor correlations ranging from .44 to .91 for the non-intensive users and from .37 to .83 for the samples of intensive ICT users.

Based on MLG analyses, further analyses in order to test whether there are differences in the estimation of the item parameter were performed.
A significant worsening in fit is obtained when the factor loadings and the covariances between the latent factors and errors are assumed to be equal for the two samples, delta $\chi^{2}(20)=95.6, p<.001$. Results from the process of constraining successive covariances and factor loadings show a final model (M6) in which: (1) two out of eight covariances between the technostrain dimensions (fatiguescepticism, fatigue-inefficacy) and between the two errors (anxiety2-anxiety3) are equal across samples (38\%), and (2) 13 out of 16 factor weights are also equal across samples $(81 \%){ }^{2}$

\section{Confirmatory factorial structure of technoaddiction among intensive ICT users}

Previous CFA on the dimensions of technoaddiction show that, unexpectedly, the one-factor model (M1) fits the data better, delta $\chi^{2}(1)=443.09$, $p<.001$, than the expected two-factor model (compulsive and excessive ICT use). Hence, CFA shows that the three-factor model (M4; with two pairs of correlated errors: anxiety2-anxiety 3 and addiction2-addiction 3$)^{3}$ fits the data better than the one-factor model (M1), delta $\chi^{2}(137)=$ $3038.15, p<.001$; the five-factor model (M2), delta $\chi^{2}(127)=639.44, \quad p<.001$; and the sixfactor model (M3), delta $\chi^{2}(88)=313.22$, $p<.001$. This final model (M4: three-factor model) is represented in Figure 2. It is interesting

\footnotetext{
${ }^{1}$ Anxiety2-anxiety3: the user's fear of destroying data or making mistakes; scepticism1-scepticism2: the lack of interest and involvement in ICT.

${ }^{2}$ Items 2, 3, and 4 for anxiety, all the items for fatigue and scepticism, and Items 1 and 2 for inefficacy in both samples.

${ }^{3}$ Anxiety2-anxiety3: the user's fear of destroying data or making mistakes; addiction2-addiction3: the excessive use of ICT outside work.
} 


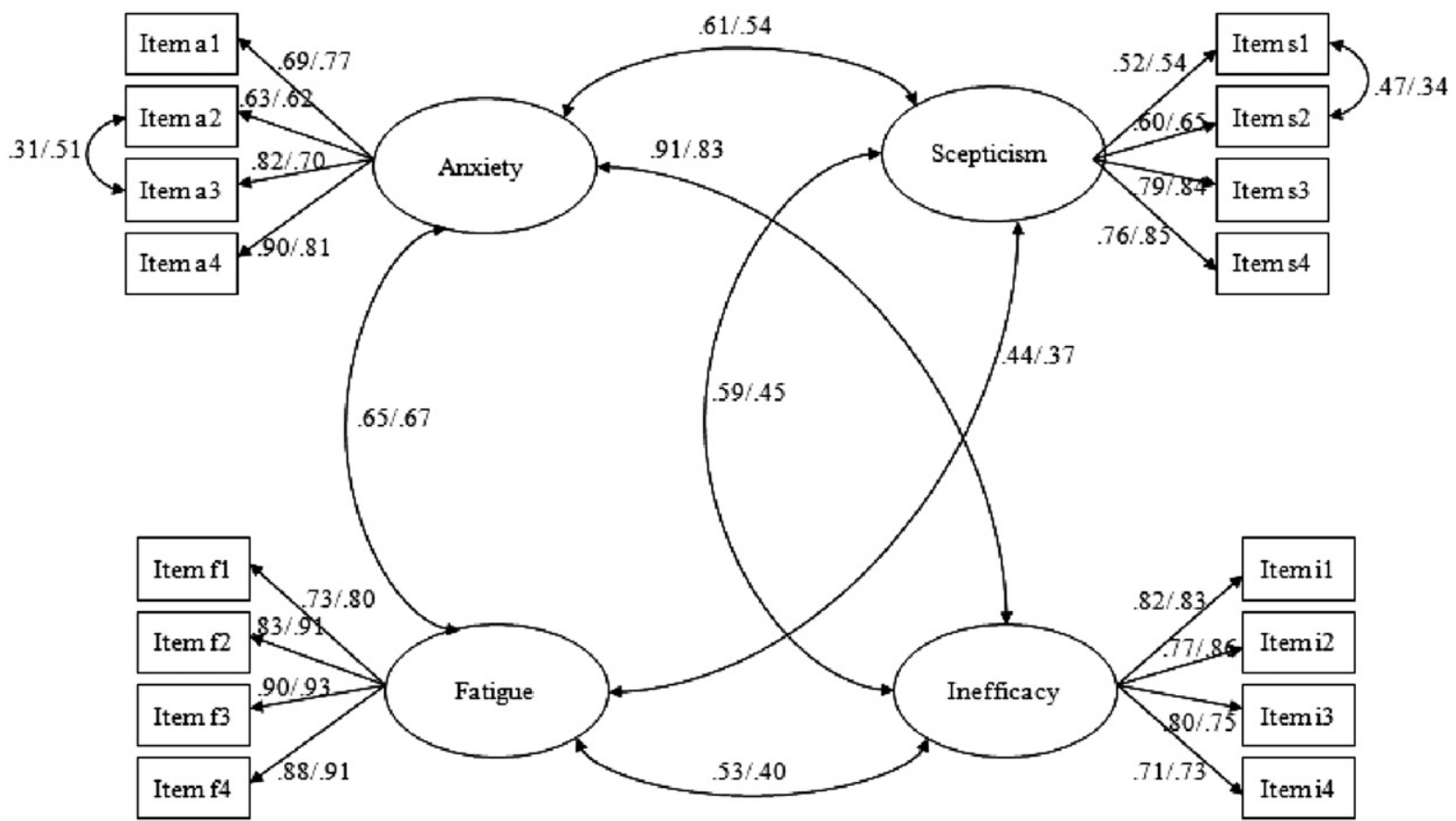

Figure 1. Structural multigroup confirmatory factor analyses of technostrain in ICT users $(N=1072)$. All coefficients (for nonintensive users/intensive users) are significant at $* * * p<.001$.

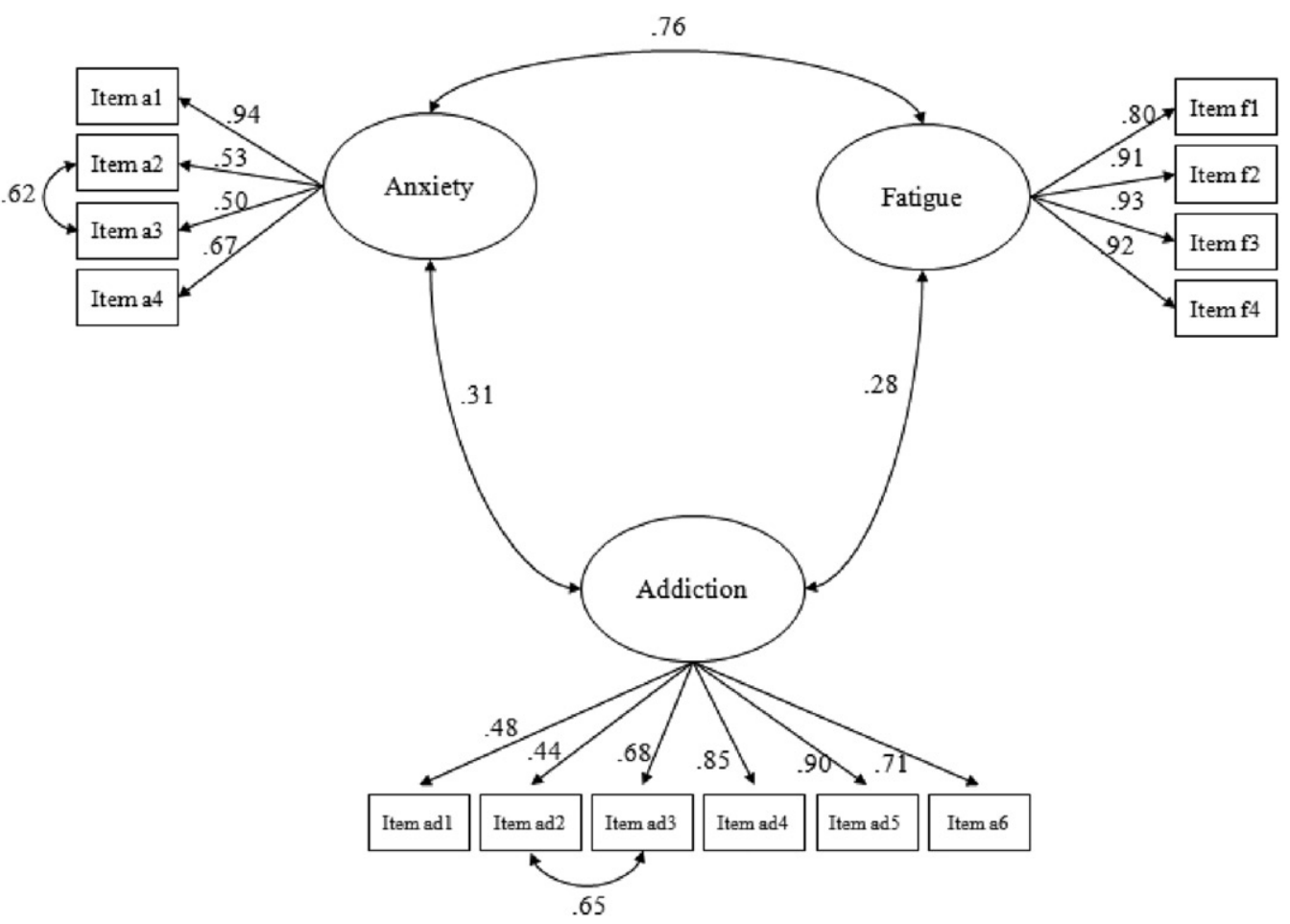

Figure 2. Structural confirmatory factor analyses of technostrain and technoaddiction in intensive ICT users $(N=397)$. All coefficients are significant at $* * * p<.001$. 
TABLE 4

Fit indices of the confirmatory factor analyses of technostrain and technoaddiction in intensive ICT users $(N=397)$

\begin{tabular}{|c|c|c|c|c|c|c|c|c|c|c|c|}
\hline Model & $\chi^{2}$ & $d f$ & $R M S E A$ & $C F I$ & $I F I$ & $A I C$ & $\chi^{2} \operatorname{diff}$ & $\triangle R M S E A$ & $\triangle C F I$ & $\Delta I F I$ & $\triangle A I C$ \\
\hline 1. Model 1: 1 factor & 3385.37 & 209 & .19 & .44 & .44 & 3473.37 & & & & & \\
\hline 2. Model 2: 5 factors & 986.66 & 199 & .10 & .88 & .88 & 1094.66 & & & & & \\
\hline Diff. M2 \& M1 & & & & & & & $2398.71 * * *$ & .09 & .44 & 44 & 2378.71 \\
\hline 3. Model 2 revised & 660.44 & 163 & .07 & .92 & .92 & 770.44 & & & & & \\
\hline Diff. M2revised \& M2 & & & & & & & $326.22 * * *$ & .03 & .04 & .04 & 324.22 \\
\hline 5. Model 3: 6 factors & 679.13 & 160 & .09 & .89 & .89 & 779.13 & & & & & \\
\hline Diff. M3 \& M2revised & & & & & & & $18.69 * * *$ & .02 & .03 & .03 & 8.69 \\
\hline 6. Model 4: 3 factor & 347.22 & 72 & .08 & .93 & .93 & 413.22 & & & & & \\
\hline Diff. M4 \& M3 & & & & & & & $331.91 * * *$ & .01 & .04 & .04 & 365.91 \\
\hline Diff. M4 \& M2revised & & & & & & & $313.22 * * *$ & .01 & .01 & .01 & 357.22 \\
\hline Diff.M4 \& M2 & & & & & & & $639.44 * * *$ & .02 & .05 & .05 & 681.44 \\
\hline Diff.M4 \& M1 & & & & & & & $3038.15^{* * *}$ & .11 & .49 & .49 & 3060.15 \\
\hline
\end{tabular}

$\chi^{2}=$ Chi-square; $\mathrm{df}=$ degrees of freedom; RMSEA = root mean square error of approximation; $\mathrm{CFI}=$ comparative fit index; $\mathrm{IFI}=$ incremental fit index; $\mathrm{AIC}=$ Akaike information criterion; $* * * p<.001$.

to note that: (1) using ICT excessively and using ICT compulsively could actually represent just one dimension; (2) factor weight values are higher than .44 ; (3) latent factor correlations range from .28 to .76 ; and (4) the positive and significant covariances among technoaddiction and the two dimensions of technostrain, i.e., anxiety and fatigue (see Table 4 and Figure 2).

\section{Multiple analyses of variance of technostress and ICT users}

MANOVAs taking ICT use (non-intensive and intensive users) as the independent variable and the four dimensions of technostrain (anxiety, fatigue, scepticism, inefficacy) as the dependent variables show significant multivariate effects of ICT use: Wilks' lambda $=.96, F(4,1067)=11.64, p<.001$, multivariate $\eta^{2}=.042$. The follow-up ANOVAs indicate that the mean effect of (non-intensive or intensive) ICT use is significantly different for anxiety, $F(1,1072)=15.73, p<.001, \eta^{2}=.014$, $d=.00 ; \quad$ scepticism, $\quad F(1,1072)=5.04, \quad p<.05$, $\eta^{2}=.005, d=.2$; and inefficacy, $F(1,1072)=26.01$, $p<.001, \eta^{2}=.024, d=.33$. Compared to the intensive users, the non-intensive users show significantly more anxiety (mean values $=1.13, .86$ ), scepticism (mean values $=1.32,1.16$ ), and inefficacy (mean values $=.98, .65$ ) in the use of ICT. However, nonsignificant differences were obtained in the fatigue dimension of technostrain, $F(1$, $1072)=1.79, p=.181$.

\section{Multiple analyses of variance of technostress predictors and ICT users}

Table 5 gives the descriptive analyses and Cronbach's alpha of the job demands, as well as job and personal resources for both ICT samples (non-intensive and intensive users). The alpha values meet the criterion of .70 (Nunnally \& Bernstein, 1994) in all the cases. As expected, the pattern of correlations shows that job demands are significantly related to job and personal resources among non-intensive $(80 \%$ of the cases) and intensive ( $73 \%$ of the cases) users (see Table 5).

Secondly, MANOVA taking ICT use (nonintensive and intensive users) as the independent variable and the dimensions of technostrain (anxiety, fatigue, scepticism, inefficacy) as the dependent variables shows significant multivariate effects of ICT use: Wilks' lambda $=.36, F(14$, $1062)=133.91, \quad p<.001$, multivariate $\eta^{2}=.64$. The follow-up ANOVAs (Table 6) indicate that the mean effect of (non-intensive and intensive) ICT use is significantly different for: (1) job demands, in terms of role ambiguity, $F(1$, $1077)=16.05, p<.001, \eta^{2}=.015, d=.26$; monotony, $F(1,1077)=63.52, p<.001, \eta^{2}=.05, d=.51$; mental overload, $F(1,1077)=10.67, p<.01$, $\eta^{2}=.010, \quad d=.21 ; \quad$ emotional overload, $F(1$, $1077)=7.91, p<.01, \eta^{2}=.007, d=.17$; mobbing, $F(1,1077)=73.73, p<.001, \eta^{2}=.064, d=.57$; and obstacles hindering ICT use, $F(1,1077)=263.72$, $p<.001, \eta^{2}=.197, d=.43$; (2) for job resources in terms of autonomy, $F(1,1077)=13.22, p<.001$, $\eta^{2}=.012, d=.24 ;$ transformational leadership, $F(1,1077)=15.52, p<.001, \eta^{2}=.014, d=.24$; social support, $F(1,1077)=707.35, \quad p<.001$, $\eta^{2}=.397, d=.76 ;$ ICT use facilitators, $F(1$, $1077)=47.23, p<.001, \eta^{2}=.042, d=.44$; as well as (3) for personal resources in terms of mental competence, $F(1,1077)=6.53, p<.05, \eta^{2}=.006$, $d=.33$, and emotional competence, $F(1$, $1077)=9.48, p<.01, \eta^{2}=.009, d=.17$. However, 
TABLE 6

Descriptive analyses, internal consistencies (Cronbach's $\alpha$ ) and ANOVA for job demands, job resources, and personal resources for nonintensive $(N=675)$ and intensive $(N=397)$ ICT users

\begin{tabular}{|c|c|c|c|c|c|c|c|c|}
\hline & \multicolumn{3}{|c|}{ Non-intensive users } & \multicolumn{3}{|c|}{ Intensive users } & \multirow[b]{2}{*}{$F_{(1,1077)}$} & \multirow[b]{2}{*}{$\eta^{2}$} \\
\hline & $M$ & $S D$ & $\alpha$ & $M$ & $S D$ & $\alpha$ & & \\
\hline 1. Work overload & 3.34 & 1.51 & .88 & 3.48 & 1.13 & .88 & 2.37 & .002 \\
\hline 2. Role ambiguity & 2.19 & 1.50 & .85 & 2.55 & 1.21 & .88 & $16.05 * * *$ & .015 \\
\hline 3. Role conflict & 2.62 & 1.48 & .88 & 2.57 & 1.12 & .83 & .31 & .000 \\
\hline 4. Monotony & 4.01 & 1.68 & .90 & 3.23 & 1.30 & .91 & $63.52 * * *$ & .05 \\
\hline 5. Mental overload & 4.60 & 1.24 & .74 & 4.36 & .95 & .71 & $10.67 * *$ & .010 \\
\hline 6. Emotional overload & 3.69 & 1.19 & .83 & 3.48 & 1.16 & .83 & $7.91 * *$ & .007 \\
\hline 7. Mobbing & 1.01 & 1.25 & .80 & .42 & .74 & .72 & $73.73^{* * *}$ & .064 \\
\hline 8. ICT use obstacles & 4.35 & 1.48 & .88 & 2.81 & 1.51 & .90 & $263.72 * * *$ & .197 \\
\hline 9. Autonomy & 4.29 & 1.32 & .80 & 4.57 & 1.03 & .87 & $13.22 * * *$ & .012 \\
\hline 10. Transformational leadership & 3.69 & 1.51 & .94 & 4.05 & 1.44 & .94 & $15.52 * * *$ & .014 \\
\hline 11. Social support & 4.86 & 1.14 & .70 & 3.11 & .82 & .70 & $707.35^{* * *}$ & .397 \\
\hline 12. ICT use facilitators & 3.33 & 1.30 & .79 & 3.87 & 1.14 & .81 & $47.23^{* * *}$ & .042 \\
\hline 13. Mental competences & 4.79 & 1.01 & .74 & 4.63 & .85 & .76 & $6.53^{*}$ & .006 \\
\hline 14. Emotional competences & 4.30 & 1.07 & .85 & 4.10 & 1.01 & .86 & $9.48^{* *}$ & .009 \\
\hline
\end{tabular}

Note: $* * * p<.001, * * p<.01, * p<.05, F=$ effect size, $\eta^{2}=$ eta.

TABLE 7

Linear regression analyses of job demands, job resources and personal resources on technostrain for (nonintensive and intensive) ICT users $(N=1072)$

\begin{tabular}{|c|c|c|c|c|c|c|c|c|c|c|c|c|}
\hline & \multicolumn{3}{|c|}{ Anxiety } & \multicolumn{3}{|c|}{ Fatigue } & \multicolumn{3}{|c|}{ Scepticism } & \multicolumn{3}{|c|}{ Inefficacy } \\
\hline & $B$ & $S E B$ & $\beta$ & $B$ & $S E B$ & $B$ & $B$ & $S E B$ & $\beta$ & $B$ & $S E B$ & $\beta$ \\
\hline 1. Work overload & -.037 & .033 & -.45 & .090 & .042 & $.087 *$ & .062 & .040 & .062 & -.007 & .030 & -.009 \\
\hline 2. Role ambiguity & .037 & .036 & .048 & .111 & .046 & $.112 *$ & .056 & .044 & .059 & .034 & .033 & .048 \\
\hline 3. Role conflict & .004 & .043 & .005 & -.007 & .055 & -.007 & .011 & .052 & .011 & -.049 & .039 & -.066 \\
\hline 4. Monotony & .018 & .025 & .026 & -.006 & .031 & -.006 & -.047 & .030 & -.054 & .012 & .023 & .019 \\
\hline 5. Mental overload & .015 & .042 & .016 & .021 & .053 & .017 & -.044 & .050 & -.037 & -.026 & .038 & -.029 \\
\hline 6. Emotional overload & .049 & .043 & .052 & -.023 & .054 & -.020 & -.077 & .052 & -.067 & .079 & .039 & $.092 *$ \\
\hline 7. Mobbing & .117 & .039 & $.122 *$ & .054 & .049 & .044 & .080 & .047 & .069 & .122 & .035 & $.141^{* *}$ \\
\hline 8. ICT use obstacles & .011 & .025 & .017 & .074 & .031 & $.090^{*}$ & -.007 & .030 & -.009 & -.001 & .022 & -.002 \\
\hline 9. Autonomy & -.094 & .034 & $-.104 *$ & -.040 & .043 & -0.36 & .015 & .041 & .014 & -.077 & .031 & $-.095^{*}$ \\
\hline 10. Transformational Leadership & .044 & .030 & .060 & .018 & .038 & .019 & -.070 & .036 & $-.078 *$ & .038 & .027 & .057 \\
\hline 11. Social support & .054 & .032 & .066 & -.093 & .040 & $-.090^{*}$ & .019 & .038 & .079 & .084 & .029 & $.114 * *$ \\
\hline 12. ICT use facilitators & -.066 & .031 & $-.076^{*}$ & -.042 & .039 & -.038 & -.061 & .037 & -.058 & -.034 & .028 & -.044 \\
\hline 13. Mental competence & -.078 & .050 & -.067 & -.070 & .063 & -.048 & -.067 & .060 & -.047 & -.111 & .045 & $-.106^{*}$ \\
\hline 14. Emotional competence & -.069 & .049 & -.064 & -.068 & .061 & -.050 & -.085 & .058 & -.065 & -.057 & .044 & -.059 \\
\hline $\mathrm{R}^{2}$ & & .067 & & & .060 & & & .059 & & & .069 & \\
\hline$\Delta \mathrm{R}^{2}$ & & .008 & & & .004 & & & .006 & & & .013 & \\
\hline
\end{tabular}

Note: ${ }^{* *} p<.01,{ }^{*} p<.05$.

nonsignificant differences were obtained in both work overload and role conflict.

Compared to the intensive users, the nonintensive users show significantly more: (1) job demands: monotony, mental overload, emotional overload, mobbing, and technological obstacles; but (2) also more resources in terms of social support, mental competences, and emotional competences. Moreover, they show significantly less role ambiguity, autonomy, transformational leadership, and technological facilitators (job resources).

\section{Linear multiple regression analyses and 'predictors' of technostress}

Tables 7 and 8 give the results of the two linear multiple regression analyses conducted by means of the forced method in order to test the 
TABLE 8

Linear regression analyses of job demands, job resources, and personal resources on technoaddiction for intensive ICT users $(N=397)$

\begin{tabular}{|c|c|c|c|c|c|c|c|c|c|}
\hline & \multicolumn{3}{|c|}{ Anxiety } & \multicolumn{3}{|c|}{ Fatigue } & \multicolumn{3}{|c|}{ Addiction } \\
\hline & $B$ & $S E B$ & $\beta$ & $B$ & $S E B$ & $\beta$ & $B$ & $S E B$ & $\beta$ \\
\hline 1. Work overload & -.027 & .047 & -.034 & .189 & .070 & $.156^{* * *}$ & .238 & .068 & $.206^{* *}$ \\
\hline 2. Role ambiguity & .119 & .051 & $.160^{*}$ & .148 & .076 & $.130^{*}$ & .087 & .074 & .081 \\
\hline 3. Role conflict & -.045 & .060 & -.056 & .076 & .091 & .062 & .010 & .089 & .008 \\
\hline 4. Monotony & .046 & .037 & .066 & .060 & .055 & .056 & -.106 & .054 & -.105 \\
\hline 5. Mental overload & .048 & .059 & .051 & .082 & .089 & .056 & .004 & .086 & .003 \\
\hline 6. Emotional overload & .066 & .053 & .085 & .008 & .080 & .007 & -.077 & .078 & -.068 \\
\hline 7. Mobbing & .253 & .072 & $.207 * * *$ & .155 & .108 & .084 & .172 & .105 & $.098^{*}$ \\
\hline 8. ICT use obstacles & -.023 & .032 & -.039 & .040 & .048 & .044 & .034 & .046 & .039 \\
\hline 9. Autonomy & -.026 & .051 & -.030 & -.055 & .076 & -.041 & -.062 & .074 & -.049 \\
\hline 10. Transformational leadership & .010 & .038 & .016 & .038 & .057 & .039 & .007 & .056 & .008 \\
\hline 11. Social support & .051 & .057 & .046 & -.006 & .086 & -.004 & -.016 & .084 & -.010 \\
\hline 12. ICT use facilitators & -.026 & .042 & -.032 & .063 & .063 & .052 & .049 & .061 & .042 \\
\hline 13. Mental competence & -.101 & .063 & -.095 & -.096 & .096 & -.060 & -.095 & .093 & -.062 \\
\hline 14. Emotional competence & -.106 & .058 & $-.118^{*}$ & -.081 & .088 & -.060 & .133 & .086 & .103 \\
\hline $\mathrm{R}^{2}$ & & .120 & & & .139 & & & .098 & \\
\hline$\Delta \mathrm{R}^{2}$ & & .020 & & & .006 & & & .007 & \\
\hline
\end{tabular}

Note: $* * * p<.001, * * p<.01, * p<.05$.

relationship of job demands, job resources, and personal resources on technostrain (non-intensive and intensive technology users) and technoaddiction (only in intensive technology users), respectively.

The results given in Table 7 for non-intensive and intensive users indicate that job demands, job resources, and personal resources predict each dimension of technostrain (anxiety, fatigue, scepticism, and inefficacy). A review of the regression weights reveals that, as expected, technostrain is "predicted" by: (1) job demands in terms of work overload (fatigue, $\beta=.087, p<.05$ ), role ambiguity (fatigue, $\beta=.112, p<.05$ ), emotional overload (inefficacy, $\beta=.092, \quad p<.05$ ), mobbing (anxiety, $\beta=.122, p<.05$; inefficacy, $\beta=.141$, $p<.01$ ), and obstacles hindering ICT use (fatigue, $\beta=.090, p<.05$ ); (2) lack of job resources, i.e., lack of autonomy (anxiety, $\beta=-.104, p<.05$, and inefficacy, $\beta=-.095, p<.05$ ), transformational leadership (scepticism, $\beta=-.078, p<.05$ ), social support (fatigue, $\beta=-.090, p<.05$, and inefficacy, $\beta=.114, p<.01)$, and ICT use facilitators (anxiety, $\beta=-.076, \quad p<.05$ ); and (3) lack of personal resources in terms of mental competences (inefficacy, $\beta=-.106, p<.05$ ). It is interesting to note that, surprisingly, social support is negatively associated with fatigue, $\beta=-.090, p<.05$, but positively associated with inefficacy, $\beta=.114$, $p<.01$.

Results in Table 8 for intensive users indicate that job demands, job resources and personal resources are related to each dimension of technoaddiction (anxiety, fatigue, and addiction). A review of the regression weights reveals that, as expected, technoaddiction is predicted by: (1) job demands in terms of work overload (fatigue, $\beta=.156, \quad p<.01$, and addiction, $\beta=.206$, $p<.01$ ), role ambiguity (anxiety, $\beta=.160$, $p<.05$, and fatigue, $\beta=.130, p<.05)$, mobbing (anxiety, $\beta=.207, \quad p<.001$, and addiction, $\beta=.098, \quad p<.05$ ); and (2) lack of personal resources, in terms of emotional competence (anxiety, $\beta=-.118, p<.05$ ).

All in all, these results provide evidence for the following findings. Firstly, job demands (work load, role ambiguity, emotional overload, mobbing, and obstacles), lack of job resources (autonomy, transformational leadership, social support, and facilitators) and lack of personal resources (mental competence) are related to technostrain (anxiety, fatigue, scepticism, inefficacy). And secondly, job demands (work overload, role ambiguity and mobbing) and lack of personal resources (emotional competence) are more specifically related to technoaddiction.

\section{DISCUSSION}

The aim of the current study was to test two technostress experiences (i.e. technostrain and technoaddiction) in a sample consisting of 1072 ICT users $(\mathrm{N}=675$ non-intensive ICT users and $N=397$ intensive ICT users), as well as to determine its main predictors. More specifically, 
first we proposed that the psychological experience of technostress is a multidimensional construct that includes two main specific psychological experiences: technostrain (anxiety, fatigue, scepticism, and inefficacy) and the more specific technoaddiction (using ICT excessively and compulsively with feelings of anxiety and fatigue). Second, we expected job demands to be positively related to technostrain and technoaddiction, while job and personal resources would be negatively related to technostrain and technoaddiction.

Findings concerning the factorial validity of the technostrain experience showed, as expected, the four-factor structure of technostrain in both samples, together with a positive and significant correlation with all the scales. Results therefore supported our Hypothesis 1. Additional data analyses showed, however, that this technostress is experienced with a different intensity in the two samples, the non-intensive ICT users experiencing significantly more anxiety, scepticism, and inefficacy than intensive ICT users.

Second, we found that the technoaddiction experience among intensive ICT users is characterized by only one dimension, which refers to an excessive and compulsive use of ICT. Results showed that in intensive ICT users, the two technostress experiences (i.e., technostrain and technoaddiction) are positively interrelated. Specifically, technoaddiction is positively and significantly related to the two affective dimensions of technostrain, i.e., anxiety and fatigue. These findings support the idea that technostrain and technoaddiction are two different but interrelated experiences of technostress in intensive ICT users. It is interesting to note that the fact the affective components (i.e., anxiety and fatigue) are shared reveals that both experiences involve feelings of "not feeling well" while using ICT. This does not happen with the other components of technostrain; that is, the attitudinal (i.e., scepticism) and the cognitive (i.e., inefficacy) components.

However, technoaddiction does not consist of two independent and positively correlated dimensions (i.e., excessive and compulsive work with ICT), but rather just one dimension. Despite this, as expected, the items that make up this one dimension of technoaddiction reflect the essence of both elements, that is to say, an excessive and compulsive use of ICT, although two independent dimensions were not found. All in all, results therefore partially supported our Hypothesis 2.

Thirdly, and as expected, job demands, job resources, and personal resources are predictors of technostrain and technoaddiction; job demands and job/personal resources being negatively related to both of them. These findings support Hypothesis 3. However, we went a step further by carrying out other data analyses, with some interesting results. First, compared to the intensive users, the non-intensive users experienced: (1) significantly more anxiety, more scepticism, and more inefficacy in terms of technostress; and (2) more job demands (in terms of monotony, mental overload, emotional overload, mobbing, and obstacles hindering ICT use), but also resources in terms of social support, and mental and emotional competences. But they showed significantly fewer job resources in terms of role ambiguity, autonomy, transformational leadership, and ICT use facilitators. Second, each different experience of technostress has specific job demands and job/personal resources related with it. It is interesting to notice that some job demands are predictors of both technostrain and technoaddiction, such as work overload, role ambiguity, and mobbing. Other job demands are specific predictors of technostrain (such as emotional overload and obstacles hindering ICT use). Job resources, on the other hand, act as predictors of technostrain, but not technoaddiction. Finally, as far as personal resources are concerned, mental competences predict technostrain and emotional competences predict technoaddiction.

Thus, our study supports the claim that technostrain and technoaddiction are two independent but related negative psychological experiences, since it shows that they are not predicted by the different job demands and job/personal resources.

Finally, it is interesting to note an unexpected result in our study. We found that, surprisingly, social support plays a double role in the prediction of technostrain due to the fact that it is negatively associated with fatigue and positively associated with inefficacy. In other words, the more social support there is, the less fatigue but the more feelings of inefficacy will be experienced. An indepth analysis of this result shows that when users get social support from others (colleagues, supervisors, etc.) while working with ICT, they feel less fatigued and exhausted due to this social support. However, they can also feel inefficacious, as they did not solve the problem by themselves but with a little help from others. According to Social Cognitive Theory (Bandura, 1997, 2001), failure to cope with ICT, and the ensuing associated need to be supported socially, could be related with this lack of efficacy beliefs.

An alternative explanation of the negative effects of social support, at least in the feelings of efficacy, is related with the law of reciprocity in 
social relationships grounded on equity theory (Adams, 1965). This broader theory assumes that people pursue reciprocity in social relationships: what they invest and gain from a relationship should be proportional to the investments and gains of the other party in the relationship. Essentially, whenever somebody shares something, it leaves both the person sharing the information and the person receiving with a sense of obligation to reciprocate. Hence, if one colleague helps another to cope with ICT, the latter could feel inefficacious due to the fact that he/she feels obliged to reciprocate when the former has a problem in the future.

\section{Limitations and future research}

One weakness of our study is that we used selfreport measurements. Yet, because of the nature of this study, which covers psychological phenomena such as affects, attitudes, and beliefs, the use of self-reports is an appropriate method. Moreover, Harman's test (see Podsakoff et al., 2003) shows that the common method variance bias is not a serious problem in the present study.

Our study also has the following strengths: (1) the use of specific technostress scales that are focused on two technostress experiences, i.e., technostrain (the most traditional) and technoaddiction (more specific in intensive ICT users); (2) the multiple as well as separate testing of the technostress experience in non-intensive and in intensive ICT users; and (3) the study of the specific predictors of the technostress experience in ICT users.

Future studies could examine the two technostress experiences (i.e., technostrain and technoaddiction) in more samples of ICT users. Moreover, it would be interesting to study different profiles of technostress experiences based on sociodemographic and occupational variables as well. In addition, once the technostress components have been tested, the next step would be to find out more about their consequences as a whole, on one hand, and differentially by the two technostress experiences on the other.

It is also interesting to consider the intensity of ICT use within technostress studies because this could be an interesting risk factor for developing different types of technostress. Additionally, it would be interesting to conduct further research on the "ambivalent" role played by social support in the prediction of technostress; that is, as a kind of "social resource" (due to its being negatively associated with fatigue), but also as a kind of "social demand" because of its association with feelings of inefficacy.

Finally, the results of this study may have direct implications for human resources management in companies, for both non-intensive and intensive ICT users, since they provide knowledge about the psychological risks (job demands and lack of resources) associated with each category regarding their relationship with the technologies at work.

Manuscript received July 2011 Revised manuscript accepted February 2012 First published online June 2012

\section{REFERENCES}

Adams, J. S. (1965). Inequity in social exchange. In I. Berkowitz (Ed.), Advances in experimental social psychology (Vol. 2, pp. 267-299). New York, NY: Academic Press.

Al-Fudail, M., \& Mellar, H. (2008). Investigating teacher stress when using technology. Computers \& Education, 51, 1103-1110.

Bandura, A. (1997). Self-efficacy: The exercise of control. New York, NY: Freeman.

Bandura, A. (2001). Social cognitive theory: An agentic perspective. Annual Review of Psychology, 52, 1-26.

Beehr, T. A., Walsh, J. T., \& Taber, T. D. (1976). Relationship of stress to individually and organizationally valued states: Higher order needs as a moderator. Journal of Applied Psychology, 61, 41-47.

Berntson, H., \& Marklum, S. (2007). The relationship between perceived employability and subsequent health. Work \& Stress, 21, 279-292.

Brod, C. (1984). Technostress: The human cost of the computer revolution. Reading, MA: Addison-Wesley.

Byrne, B. M. (2006). Structural equation modeling with EQS: Basic concepts, applications and programming. Mahwah, NJ: Lawrence Erlbaum Associates.

Cooper, C. L., Dewe, P., \& O’Driscoll, M. P. (2001). Organizational stress: A review and critique of theory, research, and applications. Thousand Oaks, CA: Sage.

Del Líbano, M., Llorens, S., Salanova, M., \& Schaufeli, W. B. (2010). Validity of a brief workaholism scale. Psicothema, 22, 143-150.

Demerouti, E., Bakker, A. B., Nachreiner, F., \& Schaufeli, W. B. (2001). The job demands-resources model of burnout. Journal of Applied Psychology, 86, 499-512.

Deng, X., Doll, W., \& Truong, D. (2004). Computer self-efficacy in an ongoing use context. Behaviour \& Information Technology, 23, 395-412.

Everitt, B. S. (2002). The Cambridge dictionary of statistics. Cambridge, UK: Cambridge University Press.

Field, A. (2005). Discovering statistics using SPSS. London, UK: Sage.

Gaudron, J. P., \& Vignoli, E. (2002). Assessing computer anxiety with the interaction model of anxiety: Development and validation of the computer anxiety trait subscale. Computers in Human Behavior, $18,315-325$

Griffiths, M. (1995). Technological addictions. Clinical Psychology Forum, 71, 14-19. 
Hamborg, K. C., \& Greif, S. (2009). New technologies and stress.. In C. L. Cooper, J. C. Quick, \& M. J. Schabracq (Eds.), International handbook of work and health psychology (pp. 221-250). Chichester, UK: Wiley.

Henderson, R. D., Deane, F. P., \& Ward, M. J. (1995). Occupational differences in computer-related anxiety: Implications for the implementation of a computerized patient management information system. Behaviour \& Information Technology, 14, 23-31.

Huang, C. (2010). Internet use and psychological wellbeing: A meta-analysis. CyberPsychology. Behavior, and Social Networking, 13, 241-249.

Huang, R. L., Lu, Z., Liu, J. J., You, Y. M., Pan, Z. Q., Wei, Z., et al. (2009). Features and predictors of problematic internet use in Chinese college students. Behaviour \& Information Technology, 28, 485-490.

Jackson, P. R., Wall, T. D., Martin, R., \& Davis, K. (1983). New measures of job control, cognitive demand and production responsibility. Journal of Applied Psychology, 78, 753-762.

Korunka, C., Zauchner, Z., \& Weiss, A. (1997). New information technologies, job profiles, and external workload as predictors of subjectively experienced stress and dissatisfaction at work. International Journal of Human-Computer Interaction, 9, 407-424.

Larsen, R. J., \& Diener, E. (1992). Promises and problems with the circumplex model of emotion. In M. S. Clark (Ed.), Emotion (pp. 25-59). Thousand Oaks, CA: Sage.

Lewis, D. (1996). Dying for information?. London, UK: Reuters Business Information.

Maslach, C., Schaufeli, W. B., \& Leiter, M. P. (2001). Burnout. Annual Review of Psychology, 52, 397-422.

Nunnally, J. C., \& Bernstein, I. H. (1994). Psychometric theory (3rd ed.). New York, NY: McGraw-Hill.

Ookita, S. Y., \& Tokuda, H. (2001). A virtual therapeutic environment with user projective agents. CyberPsychology \& Behavior, 4, 155-167.

Parayitam, S., Desai, K. J., Desai, M. S., \& Eason, M. K. (2010). Computer attitude as a moderator in the relationship between computer anxiety, satisfaction, and stress. Computers in Human Behavior, 26, 345-352.

Podsakoff, P. M., MacKenzie, S. M., Lee, J., \& Podsakoff, N. P. (2003). Common method variance in behavioral research: A critical review of the literature and recommended remedies. Journal of Applied Psychology, 88, 879-903.

Porter, G., \& Kakabadse, N. K. (2006). HRM perspective on addiction to technology and work. Journal of Management Development, 25, 535-560.

Ragu-Nathan, T. S., Tarafdar, M., Ragu-Nathan, B. S., \& Tu, Q. (2008). The consequences of technostress for end users in organizations: Conceptual development and empirical validation. Information Systems Research, 19, 417-433.

Rizzo, J. R., House, R. J., \& Lirtzman, S. I. (1970). Role conflict and ambiguity in complex organizations. Administrative Science Quarterly, 15, 150-163.
Russell, J. A. (1980). A circumplex model of affect. Journal of Personality and Social Psychology, 39, 1161-1178.

Şahin, Y. L., \& Çoklar, A. N. (2009). Social networking users' views on technology and the determination of technostress levels. Procedia Social and Behavioral Sciences, 1, 1437-1442.

Salanova, M., Cifre, E., Llorens, S., Martínez, I. M., \& Lorente, L. (2011). Psychosocial risks and positive factors among construction workers. In C. Cooper, R. Burke, \& S. Clarke (Eds.), Occupational health and safety: Psychological and behavioral aspects of risk (pp. 295-320). Aldershot, UK: Gower.

Salanova, M., Grau, R. M., Cifre, E., \& Llorens, S. (2000). Computer training, frequency of usage and burnout: The moderating role of computer selfefficacy. Computers in Human Behavior, 16, 575-590.

Salanova, M., Llorens, S., Cifre, E., \& Nogareda, C. (2007). El tecnoestrés: Concepto, medida y prevención [Technostress: Concept, measurement and prevention]. Nota Técnica de Prevención, 730. Madrid, Spain: INSHT.

Schaufeli, W. B., \& Bakker, A. B. (2004). Job demands, job resources and their relationship with burnout and engagement: A multi-sample study. Journal of Organizational Behavior, 25, 293-315.

Schaufeli, W. B., \& Enzmann, D. (1998). The burnout companion to study and research: A critical analysis. London, UK: Taylor \& Francis.

Schaufeli, W. B., \& Salanova, M. (2007). Efficacy or inefficacy, that's the question: Burnout and engagement, and their relationships with efficacy beliefs. Anxiety, Coping \& Stress, 20, 177-196.

Schaufeli, W. B., Taris, T. W., \& Bakker, A. B. (2008). It takes two to tango: Workaholism is working excessively and working compulsively. In R. J. Burke, \& C. L. Cooper (Eds.), The long work hours culture: Causes, consequences and choices (pp. (203-226). Bingley, UK: Emerald.

Schiffrin, H., Edelman, A., Falkenster, M., \& Steward, C. (2010). The associations among computermediated communication, relationships, and wellbeing. CyberPsychology, Behavior, and Social Networking, 13, 299-306.

Van Veldhoven, M., \& Meijman, T .F. (1994). Measuring psychosocial workload by means of a questionnaire: Questionnaire on the Experience and Evaluation of Work VBBA. Amsterdam, The Netherlands: NIA.

Wallgren, L. G., \& Hanse, J. J. (2007). Job characteristics, motivators and stress among information technology consultants: A structural equation modeling approach. International Journal of Industrial Ergonomics, 37, 51-59.

Wang, K., Shu, Q., \& Tu, Q. (2008). Technostress under different organizational environments: An empirical investigation. Computers in Human Behavior, 24, 3002-3013.

Warr, P. (1987). Work, unemployment, and mental health. Oxford, UK: Oxford University Press.

Weil, M. M., \& Rosen, L. D. (1997). Technostress: Coping with technology@work,@home,@play. New York, NY: Wiley. 